\title{
HUBUNGAN KOMPETENSI PENERJEMAH DAN KUALITAS TERJEMAHAN
}

\author{
Meidya Laksmi Ariyanti ${ }^{1}$ dan Dr. Sufriati Tanjung, M.Pd. ${ }^{2}$ \\ Mahasiswa Universitas Negeri Yogyakarta ${ }^{1}$, Dosen Universitas Negeri Yogyakarta² \\ Email: meidya0274pasca2015@student.uny.ac.id / meidya1889@gmail.com
}

\begin{abstract}
Translation competencies are knowledge and abilities owned by a translator to produce good quality translations. One of the translation competencies includes the educational background and/or translation training that have been taken by the translator. Nevertheless, there are many translators in Indonesia who do not have the educational and/or translation training backgrounds. With this mind, this research analyzes the relationship between the translation training, with the quality of the translation results. From the analysis of literature stidies that have been done by several previous researchers regarding to the correlations between the translation competencies and the quality of translations, the writer found that the translation competencies affected the quality of translations produced by the translator.
\end{abstract}

Keywords: Translation Competencies, Quality of Translations, Educational and / or Translation Training

\begin{abstract}
Abstrak: Kompetensi penerjemahan merupakan pengetahuan dan kemampuan yang dimiliki penerjemah untuk menghasilkan terjemahan dengan kualitas yang baik. Kompetensi penerjemahan salah satunya meliputi latar belakang pendidikan dan atau pelatihan penerjemahan yang pernah ditempuh penerjemah. Walaupun begitu, banyak penerjemah di Indonesia yang tidak memiliki latar belakang pendidikan dan atau pelatihan penerjemahan. Berkaitan dengan hal tersebut, penelitian ini menganalisis hubungan antara kompetensi penerjemahan, khususnya latar belakang pendidikan dan atau pelatihan penerjemahan, dengan kualitas hasil terjemahan para penerjemah. Dari analisis studi pustaka yang telah dilakukan terhadap beberapa penelitian terdahulu mengenai korelasi antara kompetensi penerjemahan dengan kualitas terjemahan, peneliti menemukan bahwa kompetensi penerjemahan mempengaruhi kualitas terjemahan yang dihasilkan penerjemah.
\end{abstract}

Kata kunci: Kompetensi Penerjemahan, Kualitas Terjemahan, Latar Belakang Pendidikan dan atau Pelatihan Penerjemahan

\section{PENDAHULUAN}

Penerjemahan secara umum diartikan sebagai sebuah bentuk pengalihan kata, kalimat, paragraf, dan teks dari bahasa sumber ke bahasa target. Lebih lanjut lagi, Simatupang (2000, p. 9) menjelaskan proses penerjemahan sebagai sebuah kegiatan pengalihan makna dari bahasa sumber ke bahasa sasaran yang mana diwujudkan dalam bentuk yang sewajar mungkin, sesuai dengan aturan-aturan kebahasaan yang berlaku dalam bahasa sasaran.

Kemudian, merujuk pada kata 'sewajarnya' atau 'wajar' yang serupa artinya dengan kata 'seimbang', 'sepadan', atau 'ekuivalen' dalam Kamus Besar Bahasa Indonesia (KBBI), dalam melakukan kegiatan penerjemahan, penerjemah sangat perlu untuk 
memperhatikan keseimbangan, kesepadanan, dan ekuivalensi dari kata dan makna yang akan diterjemahkan. Beberapa ahli seperti Pinhhuck (1977, p. 38) menekankan bahwa dalam kegiatan penerjemahan yang perlu ditemukan adalah ekuivalensi dalam bahasa target untuk sebuah percakapan dalam bahasa sumber. Hal ini kemudian diperkuat oleh Bell (1991, p. 5) yang ikut pula mengatakan bahwa dalam menemukan hasil terjemahan atau ekspresi (percakapan atau tulisan) dalam bahasa lain, penerjemah harus tetap memelihara kesepadanan atau ekuivalensi semantik dan gaya bahasa dari bahasa sumber. Selanjutnya, Nida (dalam Lie, 2005) memberikan pengertian yang paling jelas mengenai proses penerjemahan sebagai berikut:

"...consists of reproducing in the receptor language the closest natural equivalent to the message of the (original) language, first in terms of meaning and secondly in terms of style. By natural, we mean that the equivalent meaning forms should not be 'foreign' either in form or meaning."

Jadi, dalam menerjemahkan sebuah teks atau percakapan penerjemah diwajibkan untuk menemukan ekuivalensi yang paling alami atau normal dalam ranah arti dan gaya dari bahasa target tersebut sehingga tidak akan menimbulkan rasa asing baik dalam bentuk maupun arti bagi pendengar atau pembaca dari negara yang berbahasa sasaran. Disamping itu, ekuivalensi paling alami dan tepat yang telah ditemukan juga akan menentukan kualitas suatu hasil terjemahan. Apabila penerjemah tidak mampu menemukan ekuivalensi dari kata-kata yang ingin diterjemahkan, maka hal tersebut juga akan mempengaruhi kualitas dari hasil akhir terjemahan.

Tingkat keberhasilan seorang penerjemah dalam menerjemahkan, profesionalitas penerjemah, dan kredibilitas penerjemah salah satunya dapat diukur dengan cara menentukan kualitas hasil terjemahan yang sudah dihasilkan. Dengan kompetensikompetensi penerjemahan yang telah dikuasai sejauh ini, dapat diukur kualitas dari terjemahan yang telah dihasilkan. Larson (1984, p. 532) menjabarkan tiga aspek yang perlu diperhatikan dalam menilai kualitas hasil terjemahan sebagai berikut:

a. Keakuratan

Keakuratan merujuk kepada kesepadanan teks bahasa sumber dan teks bahasa sasaran (Nababan et al, 2012, p. 44). Kesepadanan yang dimaksud adalah kesepadanan isi dan pesan teks. Penerjemah harus mampu mempertimbangkan hal tersebut sehingga tidak ada isi dan pesan teks yang dihilangkan, ditambahkan, atau diubah (Simatupang, 2000, p. 131). Kategori tingkat keakuratan hasil terjemahan meliputi: Akurat, Kurang Akurat, dan Tidak Akurat.

\section{b. Keberterimaan}

Keberterimaan diartikan sebagai kealamiahan suatu teks terjemahan bagi pembaca sasaran yang terkait dengan sistem bahasa dan budaya sasaran. Nababan (2012, p. 44) menjelaskan lebih lanjut bahwa, 
"istilah keberterimaan merujuk kepada apakah suatu terjemahan yang sudah diungkapkan sesuai dengan kaidah-kaidah, norma, dan budaya yang berlaku dalam bahasa sasaran atau belum, baik pada tataran mikro maupun pada tataran makro."

Aspek keberterimaan terbagi menjadi tiga tingkatan yaitu Berterima, Kurang Berterima, dan Tidak Berterima.

\section{c. Keterbacaan}

Richards (dalam Nababan, 2008, p. 62) menjelaskan bahwa aspek keterbacaan merujuk kepada seberapa mudah suatu teks terjemahan dapat dipahami oleh pembaca sasaran. Hal ini dibenarkan oleh Pinto (2001: 298) yang mengatakan bahwa "one important measurement of quality should be the clarity and readability of the final product." Lebih lanjut lagi, aspek keterbacaan terbagi ke dalam tiga tingkatan yaitu Keterbacaan Tinggi, Keterbacaan Sedang, dan Keterbacaan Rendah.

Dengan adanya ketiga aspek penilaian penerjemahan tersebut, dapat diukur kualitas suatu hasil terjemahan. Prosedur penilaian kualitas hasil terjemahan ini telah digunakan di banyak penelitian yang berkaitan dengan bidang penerjemahan sehingga kredibilitas prosedur tersebut tidak perlu diragukan lagi keakuratannya. Namun, bagaimanakah cara untuk mendapatkan skor tertinggi dalam ketiga aspek penilaian tersebut?

Shreve (dalam Nababan et al, 2004, p, mengatakan bahwa kompetensi penerjemahan merupakan bagian dari kompetensi komunikasi yang membahas tentang penerjemahan dan bagaimana cara menerjemahkan, bagaimana cara memproduksi terjemahan yang sempurna dan akurat dengan mempertimbangkan teks asal dan kepantasan menurut konteks budaya daerah/negara asal dan sasaran. Jadi, kompetensi penerjemahan merupakan hal penting yang harus dikuasai oleh penerjemah agar menghasilkan terjemahan yang akurat, dapat diterima, dan dapat dibaca dengan baik, dengan kata lain, agar penerjemah mampu menghasilkan terjemahan dengan kualitas yang baik. Kompetensi penerjemahan sendiri umumnya terdiri dari kemampuan-kemampuan yang berkaitan dengan proses penerjemahan, mencakup ilmu pengetahuan tentang bagaimana cara menerjemahkan yang baik. Berkenaan dengan hal tersebut, menurut Gile (1995, p. 6), kompetensi penerjemahan bisa dicapai dengan cara membekali diri penerjemah dengan pengetahuan penerjemahan yang diperoleh dari pendidikan formal dan atau non-formal penerjemahan.

a. Pendidikan Formal Penerjemahan

Peserta menempuh pendidikan akademis yang berjenjang, seperti di universitas yang menyediakan program $\mathrm{S} 1, \mathrm{~S} 2, \mathrm{~S} 3$, atau program-program intensif yang membutuhkan waktu enam bulan hingga empat tahun.

b. Pendidikan Non-formal Penerjemahan Peserta menempuh pendidikan di pelatihan-pelatihan khusus penerjemahan dengan jangka waktu yang relatif lebih pendek daripada pendidikan formal penerjemahan. Pilihan pendidikan tersebut tidak mengharuskan peserta 
untuk menempuhnya secara berjenjang sehingga siapapun bisa mengikuti pelatihan tersebut (Christian, 2015: 16).

Dengan mengikuti pendidikan formal dan atau non-formal penerjemahan, para penerjemah dan calon penerjemah akan memperoleh pengetahuan teoritis dan praktikal tentang bagaimana cara untuk menjadi seorang penerjemah ahli.

Tingkat keahlian penerjemah itu sendiri oleh Presas pernah disinggung sebelumnya. Presas (dalam Nababan et al, 2004, p. 33) mengatakan bahwa terdapat empat perbedaan utama antara penerjemah ahli dengan penerjemah pemula, yaitu berdasarkan pada keterampilan khusus kebahasaan, memori dwibahasa, pengendalian interferensi pada saat memahami dan menghasilkan informasi, dan kemampuan pengalihan. Bagi penerjemah pemula, kemampuan khusus kebahasaannya tidak sedalam penerjemah ahli. Dalam bidang memori dwibahasa, penerjemah ahli dikategorikan sebagai penerjemah koordinat sedangkan penerjemah pemula dikategorikan sebagai penerjemah subordinat. Kemudian, dalam kaitannya dengan pengendalian interferensi, penerjemah ahli dapat mengendalikan interferensi dengan baik saat memahami dan menghasilkan informasi sedangkan penerjemah pemula tidak bisa melakukan hal tersebut sebaik penerjemah ahli. Yang terakhir, dalam hal kemampuan pengalihan, penerjemah ahli cenderung mempertimbangkan proses pengalihan pada tataran teks sedangkan penerjemah pemula memandang penerjemahan sebagai sebuah proses alih kode pada tataran kata, seperti seorang dwibahasawan. Jadi, dapat diasumsikan bahwa penerjemah ahli memiliki kompetensi penerjemahan yang lebih tinggi daripada penerjemah pemula karena pengetahuan dan keahlian yang mereka miliki lebih banyak dan lebih dalam. Secara langsung hal tersebut akan mempengaruhi kualitas hasil terjemahan, yang berakibat pada tinggi atau rendahnya tingkat kualitas terjemahan.

Dalam tesisnya yang berjudul Studi Kasus Profil Penerjemah Semi-profesional Berlatar Belakang Pendidikan Penerjemahan dan tanpa Latar Belakang Pendidikan Penerjemahan serta Kualitas Hasil Terjemahan Mereka, Daniel Sabbat Christian (2015, p. 1-2) menyebutkan bahwa saat diselenggarakannya acara Forum Temu Penerbit dan Penerjemah di Universitas Atmajaya pada tanggal 23 September 2013, sebagian besar penerjemah yang hadir mengakui bahwa mereka tidak memiliki latar belakang pendidikan penerjemahan. Banyak penerjemah mengaku bahwa mereka hanya memiliki bekal kemampuan bahasa asing serta keahlian di bidang ilmu tertentu saja. Hal ini mengisyaratkan bahwa banyak penerjemah di Indonesia yang tidak memiliki latar belakang pendidikan formal maupun non-formal penerjemahan nekad memilih profesi sebagai penerjemah dengan hanya bermodalkan kemampuan berbahasa asing saja. Selain itu, hal ini juga menunjukkan bahwa peran pendidikan formal dan non-formal penerjemahan masih dikesampingkan oleh sebagian besar penerjemah karena mereka menganggap bahwa penguasaan bahasa asing 
saja sudah cukup untuk dijadikan sebagai aspek kompetensi yang harus dikuasai.

Dalam salah satu artikel elektronik Himpunan Penerjemah Indonesia (HPI) dijelaskan bahwa tidak mutlak apabila ingin memilih profesi penerjemah seseorang harus memiliki ijazah dan atau sertifikat tertentu yang berhubungan dengan ilmu penerjemahan. Namun, mereka yang ingin menjadi seorang penerjemah disarankan untuk mengambil pendidikan dan pelatihan penerjemahan guna menambah keterampilan dan menjadi nilai plus bagi seorang penerjemah. Seperti profesi lain, penerjemah masa kini dituntut untuk terus mengasah diri, memperluas pengetahuan, dan mengikuti perkembangan bahasa dan pengetahuan umum demi meningkatkan kualitas diri sebagai seorang penerjemah (HPI, 2011). Senada dengan Himpunan Penerjemah Indonesia (HPI), Listyo (2009) juga mengatakan bahwa faktanya banyak penerjemah tersumpah yang hanya memiliki satu latar belakang pendidikan formal, contohnya bahasa atau hukum. Namun, jika penerjemah menguasai kedua latar belakang ilmu tersebut, ditambah dengan disiplin ilmu yang lain, tentu akan lebih baik lagi bagi penerjemah tersebut.

Jadi, dari kedua penjelasan diatas dapat disimpulkan bahwa saat ini di Indonesia perhatian para penerjemah terhadap kompetensi penerjemahan yang berhubungan dengan pendidikan formal dan non-formal penerjemahan masih sangkat kurang. Walaupun pendidikan formal dan non-formal penerjemah bukanlah syarat mutlak yang harus dipenuhi sebagai seorang penerjemah, tetapi hal tersebut akan mampu mendorong kualitas diri penerjemah sehingga mereka mampu menghasilkan terjemahan yang lebih baik dan lebih akurat lagi.

Tujuan dari pembuatan artikel ini adalah untuk menganalisis peran kompetensi penerjemahan, khususnya yang diperoleh dari pendidikan formal dan non-formal penerjemahan terhadap kualitas hasil terjemahan mereka. Artikel ini ingin mendukung penelitian-penelitian yang serupa, serta mengajak para pembaca untuk memahami tentang pentingnya pendidikan formal dan non-formal penerjemahan demi menghasilkan kualitas terjemahan yang lebih baik.

\section{METODOLOGI PENELITIAN}

Tidak dapat dipungkiri bahwa ada dua kompetensi utama yang harus dikuasai seseorang sebelum memutuskan untuk mengambil profesi sebagai penerjemah, yaitu penguasaan bahasa asing dan bidang ilmu penerjemahan. Sebagai contoh, apabila seseorang ingin menjadi seorang penerjemah Indonesia-Inggris, ia harus menguasai bahasa Indonesia dan bahasa Inggris dengan sangat baik, serta apabila ia hendak mengambil bidang hukum sebagai spesialisasi penerjemahannya, ia harus memiliki pengetahuan yang lumayan mendalam dalam bidang hukum. Hal ini ditekankan oleh Gile (1995, p. 5) yang menyatakan bahwa:

"translators must know how to
translate. This component refers to the
conceptual framework and technical
skills. It involves comprehension of 
principles of fidelity and of professional rules of conduct, both technical and human, but it also involves techniques for knowledge acquisition, for language maintenance, for problem-solving, for decision-making."

Inti dari pernyataan Gile adalah penerjemah harus mampu memahami kerangka konsep penerjemahan secara lebih mendalam, mematuhi prinsip kesetiaan dan aturan-aturan dalam penerjemahan, serta mampu mengambil keputusan secara bijak ketika menemui permasalahan saat melakukan kegiatan penerjemahan sehingga dapat menghasilkan terjemahan yang baik dan akurat. Senada dengan Gile, Said El Shiyab (dalam Nababan, 2008, p. 2) juga menyebutkan bahwa,

"Teaching the theory of translation to students of translation is important. If theory stops short at studying the semantics, syntactic analysis of language, student translators may find themselves unable to render a text effectively and communicatively into the target language."

Jadi untuk menghasilkan terjemahan yang lebih efektif dan komunikatif, para penerjemah atau calon penerjemah perlu untuk mempelajari teori-teori dasar penerjemahan sehingga tidak akan bersikap asal-asalan dan tanpa pedoman dalam menerjemahkan sebuah teks atau percakapan.

Disamping kompetensi-kompetensi penerjemahan yang secara singkat telah diuraikan oleh Gile dan Shiyab, dalam tesisnya yang berjudul Kualitas Hasil Penerjemahan Individu dan Penerjemahan Kelompok (Studi Kasus Proses dan Hasil Penerjemahan Mahasiswa Pascasarjana Program Studi
Linguistik Minat Utama Penerjemahan UNS), Winantu Kurnianingtyas S. A. (2008, p. 17-19) juga mengkategorikan kompetensi penerjemahan ke dalam beberapa golongan yaitu:

\section{a. Linguistic Competence}

Kompetensi linguistik merupakan kompetensi paling vital yang harus dimiliki oleh seorang penerjemah karena inti dari kegiatan yang dilakukan oleh penerjemah adalah mentransfer teks dari satu bahasa ke bahasa lain sehingga kemampuan linguistik yang dimiliki penerjemah sangat mempengaruhi kualitas hasil terjemahan. Viennes (1998) menjelaskan bahwa kompetensi linguistik adalah untuk menguasai bahasa sumber dan memproduksinya kembali ke dalam bahasa sasaran.

b. Textual Competence

Schaffner menjabarkan kompetensi tekstual sebagai sebuah "knowledge of regularities and conventions of texts, genres, text types." Jadi, penerjemah harus mampu mengenali beragam jenis teks dan mampu menerjemahkan beragam jenis teks tersebut dengan teknik tertentu yang sesuai.

c. Domain/Subject Spesific Competence

Kompetensi ini berbicara tentang kemampuan penerjemah dalam menguasai materi teks yang akan diterjemahkan. Bukan berarti penerjemah harus menjadi seseorang yang ahli dalam bidang ilmu tertentu baru dapat melakukan kegiatan penerjemahan, namun penerjemah harus setidaknya 
mengerti dan memahami bidang ilmu dari teks yang diterjemahkan. Menurut PACTE (2005), hal ini berkaitan dengan pengetahuan umum dan pengetahuan khusus yang bisa dimanfaatkan sesuai dengan materi teks yang diterjemahkan.

\section{d. Cultural Competence}

Penerjemah harus menguasai atau setidaknya mengetahui kebudayaan dari kedua bahasa, bahasa sumber dan bahasa sasaran. Dengan kemampuan ini penerjemah akan dapat menemukan padanan istilah secara lebih mudah karena sudah memiliki pengetahuan yang mencukupi tentang kebudayaan dari kedua bahasa tersebut, serta penerjemah akan mampu meminimalisir kerancuan dan keasingan dari kosakata-kosakata baru yang diterjemahkan ke dalam bahasa sasaran.

e. Research Competence

Orozco dan Albir (2002, p. 376) mengatakan bahwa "strategic competence is essential because it affects the others, making up for deficiencies and solving problems in all of them." Kompetensi ini berkaitan erat dengan kemampuan penerjemah dalam memecahkan permasalahan yang terkait dengan pengambilan keputusan dalam kegiatan penerjemahan.

\section{f. Transfer Competence}

Kompetensi ini berkaitan dengan kemampuan penerjemah untuk mengalihkan pesan dari bahasa sumber ke dalam bahasa sasaran dimana penerjemah harus mampu mempertahankan makna sekaligus mengungkapkan makna dengan tepat dan jelas ke dalam bahasa sasaran.

Keenam kompetensi tersebut merupakan salah satu kompilasi kategori kompetensi yang diungkapkan oleh beberapa ahli, dan ada banyak ahli lain yang berorientasi pada bidang penerjemahan memiliki definisi dan kategori tersendiri untuk menjabarkan konsep kompetensi penerjemahan yang harus dimiliki oleh seorang penerjemah. Namun, sebagian besar ahli setuju bahwa kompetensi penerjemahan bukan hanya meliputi kompetensi bilingual saja yaitu penguasaan dua bahasa (bahasa sumber dan bahasa sasaran) atau lebih, tetapi juga meliputi kompetensi-kompetensi linguistik dan teoritis yang berhubungan dengan bidang penerjemahan. Seorang penerjemah bukan hanya bertugas untuk mengalihkan pesan dari satu bahasa ke bahasa lain, namun mereka juga dituntut untuk melakukan pengalihan bentuk, struktur, gaya, budaya, dan lain-lain. Pengalihan berbagai macam aspek dalam teks tersebut tidak cukup hanya dapat dilakukan oleh kompetensi bilingual saja.

\section{HASIL}

Setelah mengkaji teori-teori yang telah dikemukan oleh para ahli mengenai definisi dan urgensi kompetensi penerjemahan, peneliti kemudian mencari bukti-bukti penelitian yang relevan dengan topik dan menemukan bahwa ada beberapa penelitian lapangan yang telah dilakukan oleh akademisi perihal hal tersebut di Indonesia. Rata-rata peneliti 
mempertanyakan apakah kompetensi penerjemahan dalam bidang pendidikan dan atau pelatihan penerjemah tersebut penting untuk diikuti, dan meneliti pengaruh keikutsertaan dan ketidak ikutsertaan penerjemah terhadap kualitas hasil terjemahan.

Telah disebutkan sebelumnya bahwa banyak ahli yang memiliki definisi tersendiri untuk menguraikan konsep kompetensi penerjemahan, salah satunya adalah Schaffner, Adab, dan Anderson (dalam Nababan 2008, p. 35) yang mengatakan bahwa penerjemah harus memiliki pengetahuan penerjemahan agar mereka dapat menerjemahkan dengan baik. Pengetahuan ini meliputi pengetahuan deklaratif (pengetahuan tentang penerjemahan) dan pengetahuan prosedural (pengetahuan tentang cara menerjemahkan). Anderson (dalam PACTE, 2005, p. 4) kemudian menjabarkan pengetahuan deklaratif dan prosedural tersebut sebagai berikut:

"Declarative knowledge consists of knowing what: it is easily verbalised; it is acquired by being exposed to information and its use is normally controlled (e.g., knowing the addresses of web pages that are useful for translator documentation). On the other hand, procedural knowledge consists of knowing how: it is difficult to verbalise; it is acquired through practice and its use is mainly automatic (e.g., knowing how to use a web page to guarantee a translation's precision and economy)."

Dengan kata lain, pengetahuan deklaratif meliputi apa-apa saja yang harus dikuasai atau dimiliki penerjemah sebelum menerjemahkan, contohnya pengetahuan teoritis seperti pengetahuan tentang struktur dan tata bahasa sumber dan bahasa asing, kemampuan dalam menggunakan bahasa sumber dan bahasa asing, serta pengetahuan tentang budaya bahasa sumber dan bahasa asing. Disisi lain, pengetahuan prosedural melibatkan pengetahuan tentang bagaimana cara menggunakan atau mengaplikasikan pengetahuan deklaratif yang telah dimiliki, tentang langkah-langkah apa saja yang harus diambil ketika melakukan kegiatan penerjemahan seperti mempertimbangkan struktur bahasa, budaya bahasa, atau jenis teks yang ingin diterjemahkan. Pengetahuanpengetahuan semacam itu hanya dapat diperoleh melalui jalur pendidikan dan pelatihan penerjemahan. Disana, peserta didik dan pelatihan akan dibekali oleh pengetahuan teoritis dan praktikal penerjemahan secara lebih terarah dan terfokus dengan berkiblat kepada kurikulum, rancangan pembelajaran, dan silabus yang telah disusun oleh pengelola instansi pendidikan dan pelatihan sebelumnya. Sebagai contoh, dalam kurikulum jenjang pendidikan Sarjana Penerjemahan di Universitas Terbuka, mahasiswa diajarkan secara bertahap tata bahasa dan ilmu linguistik bahasa Inggris dan bahasa Indonesia selama 6 semester berturut-turut. ${ }^{1}$ Contoh lain adalah jenjang pendidikan Magister Linguistik Terapan konsentrasi Penerjemahan di Universitas Udayana. Di dalam kurikulum yang telah disusun untuk konsentrasi Penerjemahan, mahasiswa diajarkan tentang teori-teori lanjutan penerjemahan, analisis

\footnotetext{
${ }^{1}$ Informasi lebih lanjut tentang kurikulum jenjang pendidikan Sarjana Penerjemahan Universitas Terbuka dapat diakses di http://fkip.ut.ac.id/index.php/profil/19kategori/program/sarjana/16-sastra-inggris.
} 
genre teks, semantik, serta praktik penerjemahan. ${ }^{2}$ Hal ini menunjukkan bahwa bahan-bahan ajar yang diikutsertakan dalam kurikulum-kurikulum pendidikan tersebut merupakan salah satu bentuk nyata dari pengetahuan deklaratif dan pengetahuan prosedural yang dibutuhkan oleh seorang penerjemah untuk meningkatkan kemampuan penerjemahan dan kualitas hasil terjemahan. Akan sedikit berat apabila penerjemah ingin mempelajari atau memperoleh pengetahuan tersebut secara otodidak tanpa mengikuti jalur pendidikan yang resmi, dan banyak penerjemah yang kemudian hanya mengandalkan kemampuan bilingual tanpa adanya keinginan untuk meningkatkan kemampuan dalam bidang penerjemahan. Apabila penerjemah mempelajari pengetahuan tersebut secara otodidak, otomatis hal tersebut akan mempengaruhi pemahaman penerjemah, serta penerjemah juga tidak akan mendapat pengakuan resmi atau ijazah/sertifikat resmi dari instansi terkait yang sangat dibutuhkan oleh penerjemah untuk meyakinkan konsumen bahwa mereka adalah penerjemah profesional.

Dalam tesisnya yang berjudul Studi Kasus Profil Penerjemah Semi-profesional Berlatar Belakang Pendidikan Penerjemahan dan Tanpa Latar Belakang Pendidikan Penerjemahan serta Kualitas Hasil Terjemahan Mereka, Daniel Sabbat Christian (2015) meneliti dan membahas tentang latar belakang penerjemah khususnya latar belakang

\footnotetext{
${ }^{2}$ Informasi lebih lanjut tentang kurikulum jenjang Magister Linguistik Terapan konsentrasi Penerjemahan Universitas Udayana dapat diakses di http://linguistics.pps.unud.ac.id/kurikulum.
}

pendidikan penerjemahan, kualitas hasil terjemahan yang mereka hasilkan, serta hubungan antara latar belakang tersebut dan kualitas hasil terjemahan mereka. Peneliti memilih tiga orang penerjemah dengan latar belakang pendidikan dan pekerjaan yang berbeda. Dari hasil penelitian tersebut ditemukan bahwa Penerjemah 1 memiliki kualitas terjemahan yang paling baik untuk jenis teks yang sesuai spesialisasinya dan jenis teks di luar spesialisasinya, Penerjemah 2 menduduki peringkat ke-2 untuk tingkat kualitas terjemahan, dan Penerjemah 3 berada di urutan terakhir, atau dapat dikatakan bahwa Penerjemah 3 menghasilkan terjemahan dengan kualitas paling rendah. Selanjutnya, berdasarkan penelitian tersebut ditemukan bahwa latar belakang pendidikan penerjemahan (S2) yang dimiliki Penerjemah 1 memberikan pengaruh yang besar dalam menghasilkan terjemahan yang berkualitas. Hipotesis tersebut dibuktikan dengan hasil terjemahan Penerjemah 1 yang memiliki kualitas terjemahan tinggi baik dari segi keakuratan, keberterimaan, dan keterbacaan. Selain itu, jenis pekerjaan utama penerjemah juga memiliki pengaruh yang sangat besar dalam menghasilkan terjemahan dengan kualitas tinggi dibandingkan dengan dua penerjemah lain yang jenis pekerjaan utamanya kurang atau tidak relevan dengan bidang penerjemahan. Sebagai informasi tambahan, Penerjemah 2 bekerja sebagai guru Bahasa Inggris dan Penerjemah 3 bekerja sebagai seorang pemilik persewaan komputer dan penjilidan buku. 
Jika mempertimbangkan latar belakang pendidikan penerjemahan yang dimiliki penerjemah 1, sangat mungkin apabila ia memang menguasai pengetahuan deklaratif dan prosedural yang sangat dibutuhkan penerjemah dalam proses penerjemahan, seperti apa yang telah dijabarkan oleh Anderson sebelumnya. Pengetahuanpengetahuan teoritis dan praktikal tersebut didapat Penerjemah 1 dengan cara menempuh pendidikan S2 bidang Penerjemahan. Keahlian Penerjemah 1 dibuktikan dengan kualitas terjemahan Penerjemah 1 yang mendapat skor paling tinggi dari ketiga penerjemah padahal pengalaman menerjemahkan Penerjemah 1 merupakan yang paling minimal yaitu 1 tahun saja. Disisi lain, Penerjemah 2 dan Penerjemah 3 mendapat skor yang lebih rendah dari Penerjemah 1, namun Penerjemah 2 masih mendapatkan skor yang lebih tinggi dari Penerjemah 3 dengan pengalaman menerjemahkan selama 3 tahun. Hal ini terjadi disebabkan karena Penerjemah 2 masih memiliki kemampuan bahasa sasaran yang mencukupi karena telah menempuh Pendidikan Bahasa Inggris untuk jenjang S1 dan sedang berprofesi sebagai pengajar Bahasa Inggris sehingga kualitas terjemahan yang dihasilkan juga masih dapat dikategorikan sebagai baik. Namun untuk Penerjemah 3, karena tidak memiliki latar belakang pendidikan penerjemahan maupun bahasa sasaran, maka bisa diasumsikan bahwa ia tidak memiliki pengetahuan deklaratif dan prosedural penerjemahan yang mencukupi, terbukti dengan skor hasil terjemahan yang paling rendah dari ketiga penerjemah tersebut padahal memiliki pengalaman menerjemahkan selama 10 tahun.

Selanjutnya, dari lima premis dasar model holistik kompetensi penerjemahan yang diuraikan oleh PACTE (2005: 6), salah satunya menyebutkan bahwa kompetensi penerjemahan berbeda dengan kompetensi bilingual, namun kompetensi bilingual merupakan salah satu sub-kompetensi yang harus dikuasai oleh penerjemah. Kegiatan penerjemahan bukan hanya melibatkan pengalihan pesan dari satu bahasa ke bahasa lain, namun banyak hal yang harus dipertimbangkan dalam proses pengalihan tersebut, seperti (Eser, 2015, p. 6) pragmatik, sosiolinguistik, serta pengetahuan grammarleksikal dan tekstual dari tiap bahasa tersebut, dan Penerjemah 3 tidak memiliki kompetensi tersebut. Jika dikaitkan dengan penelitian yang telah disebutkan sebelumnya, Penerjemah 1 dan 2 telah mengikuti prosedur penerjemahan dengan baik sehingga menghasilkan terjemahan dengan kualitas tinggi. Namun untuk Penerjemah 3, proses penerjemahan yang ia lakukan hanya melibatkan kompetensi bilingual sehingga terjemahan yang dihasilkan memiliki kualitas yang rendah pula. Walau dari ketiga penerjemah tersebut Penerjemah 3 memiliki jam terbang yang paling tinggi namun hal tersebut tidak menjamin bahwa ia kemudian menjadi ahli dalam bidang penerjemahan. Pengalaman merupakan salah satu aspek yang mempengaruhi kualitas hasil terjemahan, namun apabila penerjemah hanya mengandalkan pengalaman saja tanpa membekalinya dengan pengetahuan teoritis 
dan praktikal yang mencukupi maka hal tersebut saja tidaklah cukup.

Serupa dengan penelitian Christian (2015) mengenai pentingnya kompetensi penerjemahan untuk menghasilkan terjemahan yang berkualitas, Surto Tri Saksono dan Rif'ah Inayati dalam penelitiannya yang berjudul "Penguatan Pelatihan Penerjemahan Bagi Penerjemah Pemula Sebagai Upaya Peningkatan Kualitas Penerjemah di Madura" juga membahas mengenai pentingnya pelatihan penerjemahan untuk meningkatkan kualitas hasil terjemahan. Dalam penelitian tersebut ditemukan bahwa sebagian besar penerjemah di Madura tidak memiliki kompetensi penerjemahan yang mencukupi. Banyak dari mereka yang tidak mengakui bahwa kompetensi-multi dibutuhkan bagi seorang penerjemah, dan kegiatan penerjemahan yang mereka lakukan hanya melibatkan kegiatan pengalihan pesan dari bahasa sumber ke bahasa sasaran dengan mengacuhkan prosedur-prosedur penerjemahan yang semestinya. Pendapat para penerjemah tersebut bertolak belakang dengan pernyataan PACTE (2005, p. 6) yang menyebutkan bahwa sub-kompetensi penerjemahan meliputi penguasaan dua bahasa, ekstralinguistik, profesional, psikologi, pengalihan, dan startegi, sedangkan bagi penerjemah-penerjemah di Madura, yang mereka kuasai dan mereka anggap penting hanya penguasaan dua bahasa. Selain itu, dari penelitian tersebut ditemukan bahwa penerjemah kurang memahami bahasa sumber dengan baik, tidak langsung mampu memahami ide utama dari teks bahasa sumber, kesulitan dalam mencari dan memadankan kata-kata yang sulit, serta kurang mampu menulis dalam bahasa sasaran. Ciri-ciri yang telah diuraikan tersebut sesuai dengan kriteria yang diajukan Presas tentang penerjemah pemula. Penerjemah pemula menurut Presas (dalam Nababan et al, 2004, p. 33) tidak memiliki kemampuan khusus kebahasaan yang mencukupi, kesulitan dalam menangkap ide pokok suatu teks, serta memiliki kemampuan pengalihan pesan teks yang masih dalam tatanan kata per kata. Kondisi tersebut jelas mempengaruhi kualitas terjemahan yang dihasilkan apabila dilihat dari tingkat keakuratan, keberterimaan, dan keterbacaan. Kualitas terjemahan penerjemah profesional dan penerjemah pemula pasti juga berbeda. Meskipun bukanlah sebuah keharusan bagi penerjemah untuk mengikuti pendidikan atau pelatihan penerjemahan apabila mereka memang menggunakan profesi penerjemah sebagai pekerjaan sampingan dan hanya terbatas pada penerjemahan-penerjemahan teks tertentu atau untuk tujuan tertentu saja, menurut Machali (2000, p. 146) dengan mengikuti pendidikan dan pelatihan penerjemahan dapat memenuhi dua hal penting yaitu:

1. Guna membantu mereka jika ingin menjadi penerjemah profesional demi pengembangan diri dan kemampuan,

2. Guna membantu pengembangan diri para penerjemah secara lebih terarah dan tepat melalui praktik bersama, lokakarya, dan belajar-mengajar secara langsung. 
Dengan meningkatkan kemampuan penerjemahan melalui pendidikan atau pelatihan penerjemahan, kualitas terjemahan yang mereka hasilkan juga akan menjadi lebih baik, dan hal tersebut tentunya akan memberikan kepuasan bagi pengguna jasa penerjemahan.

\section{SIMPULAN}

Dari pembahasan di atas mengenai hubungan antara kompetensi penerjemahan dan kualitas hasil terjemahan, khususnya yang diperoleh melalui pendidikan formal dan nonformal penerjemahan dapat disimpulkan bahwa:

1. Pendidikan formal dan atau nonformal penerjemahan penting untuk diambil oleh para penerjemah dan calon penerjemah demi mendapatkan kualitas terjemahan yang lebih baik serta meningkatkan profesionalitas dan kredibilitas penerjemah di mata para konsumen pengguna jasa penerjemahan.

2. Kompetensi penerjemahan yang didapatkan melalui pendidikan dan pelatihan meliputi pengetahuan deklaratif dan prosedural mengenai ilmu penerjemahan dan tata cara menerjemahkan yang baik dan benar. Pegetahuan-pengetahuan tersebut dimanifestasikan ke dalam beberapa kurikulum jenjang pendidikan Sarjana dan Magister yang berkonsentrasi pada bidang penerjemahan.
3. Terdapat beberapa penelitian lapangan yang dilakukan di Indonesia mengenai hal tersebut dan ditemukan bahwa memang terdapat korelasi yang positif antara latar belakang pendidikan dan atau pelatihan penerjemahan dengan kualitas hasil terjemahan. Salah satu penelitian mengukur kualitas terjemahan dari tingkat keakuratan, keterbacaan, dan keberterimaan dengan mempertimbangkan latar belakang penerjemah dan pengalaman penerjemah dengan kualitas hasil penerjemahan. Penelitian lain mengkaji kualitas terjemahan penerjemah pemula dan menemukan bahwa kualitas terjemahan yang dihasilkan masih tergolong rendah karena rata-rata penerjemah hanya mengandalkan kompetensi bilingual saja.

4. Pengalaman merupakan salah satu kompetensi penerjemahan yang menentukan kualitas hasil terjemahan penerjemah, namun bukan satusatunya kompetensi yang bisa diandalkan melainkan harus didukung oleh kompetensi penerjemahan lain yaitu pengetahuan teoritis dan praktikal (deklaratif dan prosedural) yang diperoleh melalui pendidikan dan atau pelatihan penerjemahan.

5. Selain itu, kompentensi bilingual (penguasaan dua bahasa) saja tidak cukup untuk meningkatkan kualitas hasil terjemahan, namun menurut PACTE, kompetensi tersebut 
merupakan salah satu sub-kompetensi penerjemahan yang kemudian ditunjang oleh sub-sub-kompetensi lain seperti pragmatik, sosiolinguistik, serta pengetahuan grammar-leksikal dan tekstual dari dua atau lebih bahasa yang dikuasai.

\section{DAFTAR RUJUKAN}

A., Winantu Kurnianingtyas S. (2008). Kualitas Hasil Penerjemahan Individu dan Penerjemahan Kelompok (Studi Kasus Proses dan Hasil Penerjemahan Mahasiswa Pascasarjana Program Studi Linguistik Minat Utama Penerjemahan Universitas Sebelas Maret Surakarta). Tesis. Surakarta: Universitas Negeri Sebelas Maret sebuah tesis dalam http://eprints.uns.ac.id/8221/1/80322107 200905561.pdf.

Bell, R. T. (1991). Translation and Translating: Theory and Practice. London: Longman.

Christian, D. S. (2015). Studi Kasus Profil Penerjemah Semi-profesional Berlatar Belakang Pendidikan Penerjemahan dan Tanpa Latar Belakang Pendidikan Penerjemahan serta Kualitas Hasil Terjemahan Mereka. Tesis. Surakarta: Universitas Negeri Sebelas Maret sebuah tesis dalam http://eprints.uns.ac.id/16892.pdf.

Eser, Oktay. (2015). “A Model of Translator's Competence from an Educational
Perspective". Vol. 3, No. 1. International Journal of Comparative Literature and Translation Studies. http://dx.doi.org/10.7575/aiac.ijcits.v.3n .ip.4.

Gile, Daniel. (1995). Basic Concepts and Models for Interpreter and Translator Training. Amsterdam/Philadelphia: John Benjamin Publishing Company.

Himpunan Penerjemah Indonesia. (2011). Kiat untuk Pengguna Jasa Penerjemah diakses tanggal 6 Mei 2016 dari http://www.hpi.or.id/kiat-memilihpenerjemah.

Larson, Mildred. (1984). Meaning Based Translation: A Guide to Cross Language Equivalence. Boston: University Press of America Inc.

Lie, Anita. (2005). Cooperative Learning: Mempraktikkan Cooperative Learning di Ruang-ruang Kelas. Jakarta: Grasindo.

Listyo, Indra. (2009). Penerjemah Bersumpah diakses tanggal 6 Mei 2016 dari http://blog.bahtera.org/2009/08/penerje mah-bersumpah/.

Machali, Rochayah. (2000). Pedoman Bagi Penerjemah. Jakarta: Grasindo.

Nababan, M. R. (2008). Teori Menerjemah Bahasa Inggris. Yogyakarta: Pustaka Pelajar.

Nababan, M. R., Nuraeni, Mardiana, dan Sumardiono. (2012). Pengembangan Model Penilaian Kualitas Terjemahan. Surakarta: Universitas Sebelas Maret.

Nababan, M. R., Subroto, Edi, dan Sumarlam. (2004). Keterkaitan Antara Latar 
Belakang Penerjemah dengan Proses

Penerjemahan dan Kualitas

Terjemahan. Surakarta: Universitas

Sebelas Maret.

Orozco, Mariana dan Albir, A. H. (2002).

"Measuring Translation Competence

Acquisition". Meta, XL VIII, 3, 2002.

PACTE. (2005). “Acquiring Translation

Competence: Hypotheses and

Methodological Problems in a Research

Project". In: Beeby, A., Ensinger, D.,

Presas, M. (eds.) Investigating

Translation. Amsterdam: John

Benjamins. Hal. 99-106.

Pinto, Maria. (2001). "Quality Factors in

Documentary Translation". Meta:

Translators' Journal. Vol. 46, No. 2, 2001. Hal. 288-300.

S.A., Winantu Kurnianingtyas. (2008).

Kualitas Hasil Penerjemahan Individu dan Penerjemahan Kelompok (Studi Kasus Proses dan Hasil Penerjemahan Mahasiswa Pascasarjana Program Studi Linguistik Minat Utama Penerjemahan Universitas Sebelas Maret Surakarta). Tesis. Surakarta: Universitas Negeri Sebelas Maret sebuah tesis dalam http://eprints.uns.ac.id/8221/1/80322107 200905561.pdf.

Saksono, S. T. dan Inayati, Rif'ah. "Penguatan Pelatihan Penerjemahan Bagi Penerjemah Pemula sebagai Upaya Peningkatan Kualitas Penerjemah di Madura”. http://journal.trunojoyo.ac.id/prosodi/art icle/download/51/73.
Simatupang, M. D. S. (2000). Pengantar Teori Terjemahan. Jakarta: Direktorat Jenderal Pendidikan Tinggi. 